\title{
RESIDUAL ACTIVITY STUDY OF CERTAIN GROUND SPRAYING EQUIPMENT FOR CONTROLLING BEAN CHECKED APHIDS WITH PRIMICARB INSECTICIDE ON Vicia fabae (L.) PLANTS IN EGYPT \\ Rehab A. A. Dar ${ }^{1}$ and Laila E. M.Seleman ${ }^{2}$ 1-spray technology Res., Dept., Plant Protec., Res., Inst., (A.R.C), Dokki, Giza \\ 2-Bollworm Res., Dept., Plant Protec., Res., Inst., (A.R.C), Dokki, Giza
}

\begin{abstract}
Field experiments were carried out in an area of about 2 feddan planted with bean plants variety (Sakha 2 ) Vicia faba (L).during season 2014 in $12^{\text {th }}$ December at Sakha ,Kafr Elsheikh Governorate. The selected area was split into 7 plots including control plot. Primicarb was sprayed with the rate of recommended and $3 / 4$ recomended dose rate and one treatment left without spraying as control by using Hydraulic Knapsack sprayer (Solo) (22 L./Fed.), Economy Micron ULVA sprayer (15 L/Fed.) and Conventional motor sprayer (Wisconson) (400 L/Fed.) Data indicated that, all tested doses revealed significant negative influenced on Aphis fabae survival. The most effective is total recommended dose followed by $3 / 4$ recommended dose. It could be recommended to use these compound with LV spraying equipment with not less than (15L/Fed.). The data showed that Hydraulic Knapsack sprayer (Solo) was the pest equipment to control Aphis fabae on bean plants. The rate of performance of Solo sprayer was $10 \mathrm{Fed} . / \mathrm{day}$. It was the best equipment, but the lowest rate of performance was Wisconson motor sprayer since it could spray only $2.5 \mathrm{Fed}$./day.

Keywords: Vicia fabae L., Aphis fabae, Primicarb, LV,HV and Ground spraying techniques.
\end{abstract}

\section{INTRODUCTION}

Piercing and sucking insects are dangerous pests which infested bean plants and cause great hazards to it after short period of cultivation. In Egypt, majority of interest was directed to the type, dosage of insecticides used, while a lesser attention was given to the application methods. A comparative studies on the efficiency of certain ground sprayers was carried out by (Hindy, 1992), who recorded significant variation in the spray deposit due to arrangement of the nozzles, spray technique and rate of application. The world attention was directed to minimization of spraying volumes and the costs of control pests which may be achieved by using a cheap and effective insecticide or using developmental ground spraying technique with low cost of application per feddan (Magdoline et al ,1992) and(Mathews,1992). Also, Himel (1969) defined the optimum droplet size for spraying insecticide as that, which gives best control results of the target insect with minimum insecticide and minimum ecosystem contamination. According to Bouse et al.(1986), Gohich (1983), Reichard et al.(1977) and Yates and Cowden(1985), the droplet size was a combined function of spraying equipment chemical formulation and ambient conditions. This work aimed to 
determine the best equipment and rate of application controlling fabae Aphids on bean plants under field conditions .

\section{MATERIALS AND METHODS}

Tested Compund:-

1. Primicarb (Aphox®), $50 \%$ D.G. , $50 \mathrm{gm} / 100 \mathrm{~L}$ water.

Spraying equipment tested on Bean plants:-

Three ground application machines were selected to perform the scope of this work as follows:

1. Economy Micron ULVA sprayer (15L./fed.)

2. Hand held Hydraulic Knapsack sprayer (Solo) (22 L./fed.)

3. Conventional ground motor sprayer (Wisconson) (400 L./fed.)

The tested equipment could be represented according to the technical categorization mentioned in Table (1). Calculations of productivity and rate of performance were recorded as described by Hindy (1992).

Execution of field experiments:-

\section{Arrangements of the experiments}

Field experiments were carried out during season 2014 on $12^{\text {th }}$ December in private bean field located at Sakha District, Kafr Elshiekh Governorate. The bean cultivated with variety of Sakha 2, the experiment was done under local meteorological conditions of $16^{\circ} \mathrm{C}$ average temperature, $60 \%$ average $\mathrm{RH}$ and $3 \mathrm{~m} / \mathrm{sec}$. average of wind velocity. The selected area of two feddans was split into 7 plots including control plot. The area of each plot was 6.8 kirats, four rows of Bean plants between treatments were not sprayed as barrier zones to avoid drift spray between treatments, spraying operations have not been done with any insecticides before execution the field experiment. The experimental field was sprayed with recommended and 3/4 recommended dose of Primicarb, and one treatment left without spraying as a control, respectively. In each plot twenty five bean plants were selected and remarked to define Aphis fabae adults numbers before and after spraying.

\section{Bioassay Procedure:-}

Field experiment was conducted in bean field highly infested with bean aphid Aphis fabae, on plant. In order to evaluate the tested compounds on them, pre-treatment count was recorded before spraying at five marked plants for each treatment, and post-treatment count was recorded after 3 days from treatment to determine the effect of the tested chemicals. According to Bakr et al (2014), the $2^{\text {nd }}$ spray takes place after 15 days from the $1^{\text {st }}$ spray.

Phytotoxic effect:-

It was determined by recording any color change, leaf curling or flaming up to 8 days after spraying, according to Badr et al. (1995).

Calculation and data analysis:

a. Reduction Percentages of aphids in the field experiment was calculated according to the equation of Henderson and Tilton(1955). 
b. Statistical analysis of results according to SAS (1996) for Biological studies: Duncan's for biological evaluation of insecticides in field.

Calibration and performance adjustment of the tested equipment:

- Collection and measurement of Spray deposit:

Collection of spray deposit:

Before spraying each bean treatment, a sampling line was constructed of five wire holder fixed in diagonal line inside each treatment to collect lost spray between plants; each wire holder top had a fixed water sensitive paper (Novartis Cards) on it, also, the water sensitive paper cards were put on five plants ; to collect the droplets deposit on bean leaves, were designed according to the method described by Hindy (1989). All cards were collected and transferred carefully inside paper. Involve all the data to the laboratory for measuring and calculating the number of droplets $/ \mathrm{cm}^{2}$ and its volume mean diameter (VMD) $\mu \mathrm{m}$ in all treatments.

Determination of spray deposit:

Number and size of blue spots (deposited droplets) on water sensitive papers (Novartis cards) were measured with a special scaled monocular lens (Strüben) ${ }^{\circledR}(15 \mathrm{X})$ Japanes lens. The volume mean diameter (VMD) $\mu \mathrm{m}$ and number of droplets in one square centimeter $\left(\mathrm{N} / \mathrm{cm}^{2}\right)$ were estimated according to Hindy (1992).

Table (1): Techno-Operational data of certain ground sprayers applied on bean field during season (2014).

\begin{tabular}{|c|c|c|c|}
\hline Items & $\begin{array}{c}\text { Hydraulic } \\
\text { Knapsack(Solo) } \\
\text { sprayer }\end{array}$ & $\begin{array}{l}\text { Spinning } \\
\text { disc } \\
\text { ULVA } \\
\text { sprayer }\end{array}$ & $\begin{array}{l}\text { Conventional motor } \\
\text { sprayer(Wisconson) }\end{array}$ \\
\hline Type of atomization & $\begin{array}{l}\text { Piston pump+ } \\
\text { pressure glass }\end{array}$ & Rotary & Mecanical Hydraulic \\
\hline Nozzle type & Tx-4 & $\begin{array}{c}\text { One } \\
\text { restirector }\end{array}$ & Spray gun (hollow cone) \\
\hline Pump type & Piston & - & Bean (Mechanical) \\
\hline Number of nozzles & 4 & 1 & 1 \\
\hline Pressure (bar) & 4.5 & - & 20 \\
\hline Spray tank (L.) & 20 & $1+10$ & 600 \\
\hline Rate of application (L/fed.) & 22 & 15 & 400 \\
\hline Working speed $(\mathrm{Km} / \mathrm{h})$. & 2.4 & 2.4 & 1.2 \\
\hline Swath width (m.) & 3.5 & 1.5 & 2.0 wide angle \\
\hline Flow rate (L/min.) & $4 \times 0.180$ & 0.180 & 2.5 \\
\hline Spray height $(\mathrm{m})$. & 0.75 & 0.5 & 0.5 \\
\hline Type of Spraying & \multicolumn{3}{|c|}{ Target in all sprayers } \\
\hline Productivity * (fed./h.) & 2 & 0.850 & 0.572 \\
\hline Rate of performance ${ }^{*}$ (fed./day) & 10 & 6 & 2.5 \\
\hline
\end{tabular}

* Number of spraying hours $=6$ hours daily.

* Calculations of productivity and rate of performance after Hindy (1992). 


\section{RESULTS AND DISCUSSION}

\section{Bioresidual activity of Primicarb with $3 / 4$ recommended dose rate against Aphis fabae on bean plants:}

Efficiency of Primicarb with the rate of $3 / 4$ recommended dose represented as mortality percentages after three days of treatments in Table (2) the results indicated that, the general mean reduction percentages of two sprays in population of A.fabae adults was 81.5 ,95.5 and 69 using Economy Micron ULVA sprayer, Hydraulic Knapsack sprayer(Solo) and Conventional motor sprayer (Wisconson), respectively , the droplet sizes were 165, 175 and $400-800 \mu \mathrm{m}$ and $\mathrm{N} / \mathrm{cm}^{2}$ were 158,165 and 30 for $3 / 4$ recommended dose sprayed with Economy Micron ULVA sprayer, Hydraulic Knapsack sprayer (Solo) and Conventional motor sprayer (Wisconson), respectively.

Table (2):The relationship between droplet distribution obtained by the tested ground spraying equipment and the corresponding mortality of Aphis fabae, using the recommended and $3 / 4$ recommended dose of Primicarb on bean plants, during season (2014) at Kafr El-sheikh Governorate.

\begin{tabular}{|c|c|c|c|c|}
\hline \multirow{2}{*}{$\begin{array}{l}\text { Insecticide } \\
\text { \& dose rate }\end{array}$} & \multirow[b]{2}{*}{$\begin{array}{l}\text { Tested } \\
\text { sprayer }\end{array}$} & \multirow[b]{2}{*}{ \#VMD $\mu \mathrm{m}$} & \multirow[b]{2}{*}{${ }^{*} \mathrm{~N} / \mathrm{cm}^{2}$} & \multirow{2}{*}{$\begin{array}{c}\% \text { Mortality } \\
\text { Average } \\
\text { (Mean Residual) }\end{array}$} \\
\hline & & & & \\
\hline \multirow{3}{*}{$\begin{array}{l}\text { Primicarb } \\
(37.5 \mathrm{gm} \backslash 100 \\
\text { L water) }\end{array}$} & Micron ULVA & 165 & 158 & 81.5 \\
\hline & Solo & 175 & 165 & 95.5 \\
\hline & Wisconson & $400-800$ & 30 & 69 \\
\hline \multirow{3}{*}{$\begin{array}{l}\text { Primicarb } \\
(50 \mathrm{gm} \backslash 100 \mathrm{~L} \\
\text { water) }\end{array}$} & Micron ULVA & 160 & 170 & 91.5 \\
\hline & Solo & 178 & 175 & 100 \\
\hline & Wiscoson & $400-800$ & 40 & 87 \\
\hline
\end{tabular}

\#VMD = Volume Mean Diameter.

${ }^{*} \mathrm{~N} / \mathrm{cm}^{2}=$ Number of droplets per square centimeter.

Bioresidual activity of Primicarb with total recommended dose rate against Aphis fabae on Bean plants:

Efficiency of Primicarb with total recommended dose rate represented as mortality percentages after three days of treatments in Table (2) the results indicated that, the general mean reduction percentages of two sprays in population of Aphis fabae adults were 91.5,100 and 87 using Economy Micron ULVA sprayer , Hydraulic Knapsack sprayer(Solo) and Conventional motor sprayer (Wisconson), respectively , the droplet sizes were 160,178 and $400-800 \mu \mathrm{m}$ and $\mathrm{N} / \mathrm{cm}^{2}$ were 170, 175, and 40 for recommended dose sprayed with Economy Micron ULVA sprayer , Hydraulic Knapsack sprayer(Solo), and conventional ground motor sprayer (Wisconson), respectively.

Relationship between lost spray on ground and the bioresidual activity of insecticide tested:

Data in Table (3) showed that when the high volume sprayer used , from $30-40 \%$ of total spray were lost and average mean residual mortality reduced according to the reduction in the amount of insecticide remains on 
plants ; the higest spray volume,the highest spray lost and lowest reduction in bean aphid.

Economy Micron ULVA sprayer (15 L/fed) :

Data in Table (3) showed that there was no significant difference between recommended and $3 / 4$ recommended dose in the lost spray percentages which were $7 \& 8 \%$ from the total spray volume in the case of $3 / 4$ and total recommended dose rate of Primicarb,respectively.Also, the results showed that no significant difference in percentages of $A$.fabae which were $81.5 \& 91.5 \%$ at same doses, respectively.

Hydraulic Knapsak (solo) sprayer(22 L/fed):

Data in Table (3) showed that there was no significant difference between recommended dose and $3 / 4$ recommended dose in the lost spray percentages (15.9 and $14.5 \%)$ from the total spray volume of Primicarb,respectively.Also, the results indicated that no significant difference in mortality percentages of A.fabae adults ( 100 and $95.5 \%$ ) at same doses, respectively.

Table (3):Lost spray on ground, as produced by ground spraying equipment, using Primicarb insecticide at total recommended and $3 / 4$ recommended dose against $A$. fabae on bean plants during season (2014).

\begin{tabular}{|c|c|c|c|c|c|}
\hline \multirow[b]{2}{*}{$\begin{array}{l}\text { Insecticide } \quad \& \\
\text { dose rate }\end{array}$} & \multirow{2}{*}{$\begin{array}{c}\text { Tested sprayer \& } \\
\text { spray volume } \\
\text { (L/fed.) }\end{array}$} & \multirow{2}{*}{$\begin{array}{l}{ }^{*} \mathrm{~N} / \mathrm{cm}^{2} \\
\text { of total } \\
\text { spray } \\
\text { droplet }\end{array}$} & \multirow{2}{*}{$\begin{array}{l}\mathrm{N} / \mathrm{cm}^{2} \\
\text { droplets } \\
\quad \text { (on } \\
\text { ground) }\end{array}$} & \multirow{2}{*}{$\begin{array}{c}\% \mathrm{~N} / \mathrm{cm}^{2} \text { (ground) } \\
\mathrm{N} / \mathrm{Cm}^{2} \\
\text { (Plants+ground) }\end{array}$} & \multirow{2}{*}{$\begin{array}{c}\text { \% Mortality } \\
\text { Average } \\
\text { (Mean Residual) }\end{array}$} \\
\hline & & & & & \\
\hline \multirow{3}{*}{\begin{tabular}{|l|} 
Primicarb \\
$(37.5 \mathrm{gm} \backslash 100 \mathrm{~L}$ \\
water $)$
\end{tabular}} & Micron ULVA (15) & 170 & 12 & 7 & 81.5 \\
\hline & Solo(22) & 193 & 28 & 14.5 & 95.5 \\
\hline & Wisconson(400) & 30 & 10 & 33 & 69 \\
\hline \multirow{3}{*}{$\begin{array}{l}\text { Primicarb } \\
(50 \mathrm{gm} \backslash 100 \mathrm{~L} \text { water })\end{array}$} & Micron ULVA (15) & 185 & 15 & 8 & 91.5 \\
\hline & Solo(22) & 208 & 33 & 15.9 & 100 \\
\hline & Wisconson(400) & 40 & 12 & 30 & 87 \\
\hline
\end{tabular}

${ }^{*} \mathrm{~N} / \mathrm{cm}^{2}=$ Number of droplets per square centimeter.

\section{Bioresidual activity of ground motor sprayer against Aphis fabae on bean plants:}

Distribution pattern of spray droplets in case of using ground motor sprayer was very difficult to be determined. About $40 \%$ of sensitive paper cards which hanged at various parts were completely washed with spray solution. The rest of paper cards received $22.5 \%$ of spray droplets (VMD 400 $500 \mu \mathrm{m}$ )while $37.5 \%$ of large droplets (VMD ca $800 \mu \mathrm{m}$ ) felt on the ground. This means that large quantities of spray were lost to the ground and it became evident that such classical spray volumes in the field were problematic because of run-off causing a corresponding soil pollution and loss of product.Also,there was a negative correlation between the lost spray and the corresponding mortality . 
Relationship between the tested chemical, techniques, and the mortality percentages of Aphis fabae on bean plants:

\section{Bioassay Evaluation:}

To study the influence of compound and spraying techniques before and after application Abbot's formula (1925), and Hendresson \& Tilton's formula (1955) were adopted to calculate the reduction percentages in the population. Table (4) showed that, the percentages of reduction of $A$. fabae on bean plants affected by Primicarb insecticide sprayed with certain ground application techniques during the season of (2014) using total and $3 / 4$ recommended dose. The rate of performance of Solo sprayer was 10 Fed./day. It was the best equipment, but the lowest rate of performance was Wisconson motor sprayer since it could spray only 2.5 Fed./day.

The following remarks and results were obtained:

-There was no Phytotoxic effect on bean leaves after application treatments with pesticide there was no change in the leaves color, and no leaf curling or flaming up phenomena was happened in case of recommended dose and $3 / 4$ recommended dose.

-There was a significant differences between both the distribution percentages of droplet sizes( LSD $=3.59$ for equipment,3.6055 for levels and 7.2946 for doses), for the droplets number $/ \mathrm{cm}^{2}$ (LSD= 1.6861 for equipment,3.2483 for levels and 1.995 for doses) and for reduction percentages(LSD=4.2025 for equipment, and 3.4313 for doses).

\section{Conclusion and Recommendation:}

Field experiment was carried out on infested area with bean aphids adults at early season on bean plants. For evaluation the field performance of Low-Volume spraying machines; Economy Micron ULVA sprayer (15 L/fed.), Knapsack sprayer (Solo) (22 L/fed.) and a High Volume Conventional ground motor sprayer (Wisconson) (400 L/fed.); to spray Primicarb with total and 3/4 recommended dose. A satisfactory coverage was obtained on bean plants, the droplet spectrum was obtained in field experiment was agreed with the optimum droplet sizes which mentioned by Himel (1969), in case of low volume equipment.

The best obtained result was Solo sprayer( $22 \mathrm{~L} / \mathrm{fed}$.) as spray volume, $178 \mu \mathrm{m}$ and 175 droplets $/ \mathrm{cm}^{2}$ and the lost spray on ground was5.9\%. Primicarb with total recommended dose revealed the best bioefficiacy results with the three tested sprayers,also best bioefficiacy obtained results with Solo sprayer (22 L/fed.) for both doses, and these results agreed with Hindy et al. (2004) ,Genidy et al. (2005) which recommended KZ oil and Pyriproxyfen followed by Agerin using low volume spraying because of reducing the time lost in process filling the machines, improve the homogeneity of the spray solution on the plant leaves and saving the lost spray on the ground,these results also in agreement with Bakr et al. (2014) they recommended by using Profenofos followed by Pyriproxyfen and Spinosad with Agromondo sprayer(20L/fed.). 
J. Plant Prot. and Path., Mansoura Univ., Vol. 6 (11), November, 2015

4 
Also , the lowest spray volume ,but the lowest percentage $8 \%$ of lost spraying between plants occurred by Economy Micron ULVA(15L/fed.) and gave $91.5 \%$, this results was agreed with Hindy et al. (1997), who mentioned that, there was a positive relationship between rate of application and lost spray on ground.

It could be recommended to use Primicarb with total recommended dose followed by $3 / 4$ dose rate with low volume (LV) spraying equipment with not less than (15L./fed.) which revealed successful results. There was a negative complete correlation between (VMD) and the mean residual of mortality of A.fabae while there was a positive complete correlate between $\mathrm{N} / \mathrm{cm}^{2}$ and the mean residual of mortality $A$. fabae of in all treatments.

\section{REFERENCES}

Badr, A.N.; El-Sisi, G.A. and Abdel Meguid, M.A. (1995): Evaluation of some locally formulated petroleum oils for controlling cotton leaf worm. J. Agric. Sci. Mansoura Univ., 20(5): 2557-2562.

Bakr, R. F.; Hindy, M.A., Ahmed, N. S., Genidy, N. A. and Dar, R. A. (2014): Field comparison between droplet distribution and the bioresidual activity of different insecticides against Spodoptera littoralis (Boisd) by using certain ground spraying equipment on cotton plants. J. Egypt. Acad. Soc. Biolo. Sci. 7(1):187-193.

Bouse L.F., Cariton, J.B. and Jank P.C. (1986): use of polymers for control of spray droplet size. ASAE. Paper No. 86:71.

Genidy, N.A.; Bakr, R. F.; Hindy, M. A. and Dar, R. A. (2005): Bioresidual activity of certain insecticides against Spodoptera littoralis (Boisd) by using low volume ground spraying equipment on cotton plants. J. Egypt. Acad. Soc. Enviro. Develop., (A-Entomology), 6(1): 1-21.

Gohich, H. (1983): Assessment of spray drift in sloping vineyards. Gopprot. 2(1):37-49.

Henderson, C.F. and Tilton, E.W.(1955): Tests with acaricides against the brown wheat mite. J. Econ. Entomol., 48:157-161.

Himel, C.M. (1969): The optimum size for insecticide spray droplets. J. Econ. Entomol., 62 (4): 919-925.

Hindy, M.A. (1992): Qualitative distribution of watery dyed spray produced by certain ground sprayers in cotton. Bull. Ent. Soc., Egypt 19:221-7.

Hindy, M.A.(1989): Residual activity of certain insecticides as affected by aerial application parameters. Ph.D. Thesis. Fac. Agric. Ain Shams Univ., Egypt, 177 pp.

Hindy, M.A.; El-Sayed, A.M.; Abd El-Salam, S.M. and Samy, M.A. (1997): Qualitative assessment of certain insecticides applied by different ground sprayers against whitefly, Bemicia tabaci (Geen.) on eggplant. Egypt. J. Agric. Res., 75 (3): 565-577. 
Hindy, M.A.;Bakr, R.F.; Genidy, N.A. and Dar, R.A. (2004) :Qualitative distribution of certain insecticides deposits and artificial targets on the cotton leafworm larvae by using certain ground spraying equipment on cotton plants .J. Egypt. Acad . Soc . Environ . Develop . ( A . Entomology ) , 5 (2) : 91-112

Magdoline, A. S.;Mohamed K. E. and Safwat, H. Y. (1992): Less soil contamination with pesticides through modification and implemention of ground application techniques.Egypt.J.Appl.Sci.,7(7):157-170.

Matthews,G.A.(1992):Pesticide application methods. $2^{\text {nd }}$ edition,Longman Harlow Publ.,U.K.,405 PP.

Reichard, D.L., Retzer, H.J. Liljedahi L.A. and Hall F.R. (1977): Spray droplet size distribution delivered by air blast orchard sprayers. Trans. ASAE 20(1):232-7,242.

SAS, (1996): Statistical analysis system. SAS user's guide: statistics. SAS Institute Inc. Editors, Cary, NC.

Yates, W.E., and Cowden, R.E. (1985): Drop size spectra from low drift systems. Trans. ASAE paper No- AA85-002(22pp.)

دراسة نشاط الاثر الباقى لبعض الات الرش الأرضية لمكافحة من الفول باستخدام مبيد

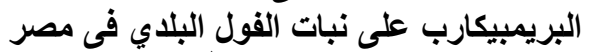

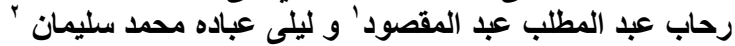

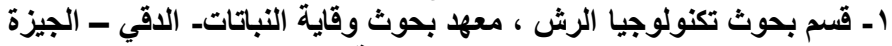

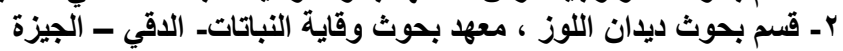

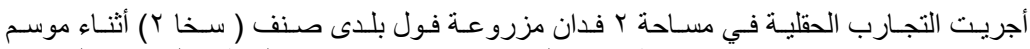

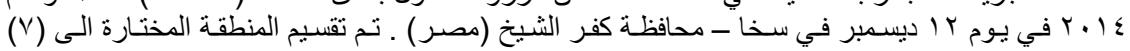

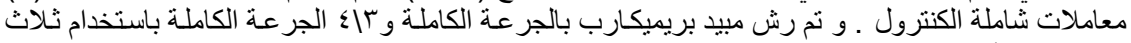

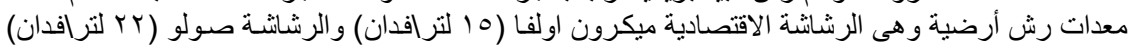

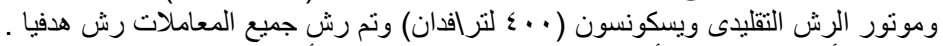

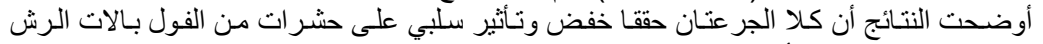

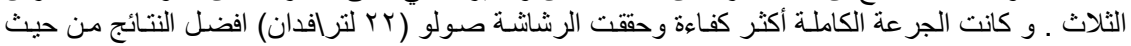

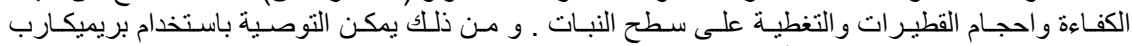

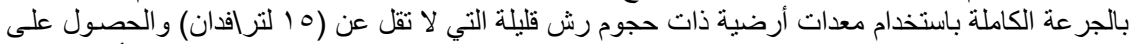

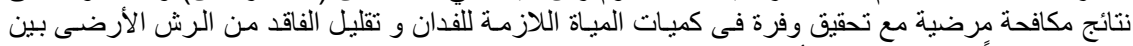

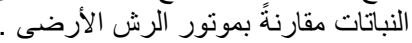

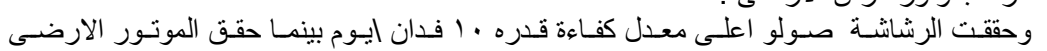
ويسكونسون اقل معدل كفاءة فى الرش وقدر ها ها ه ب فدان /يوم . 


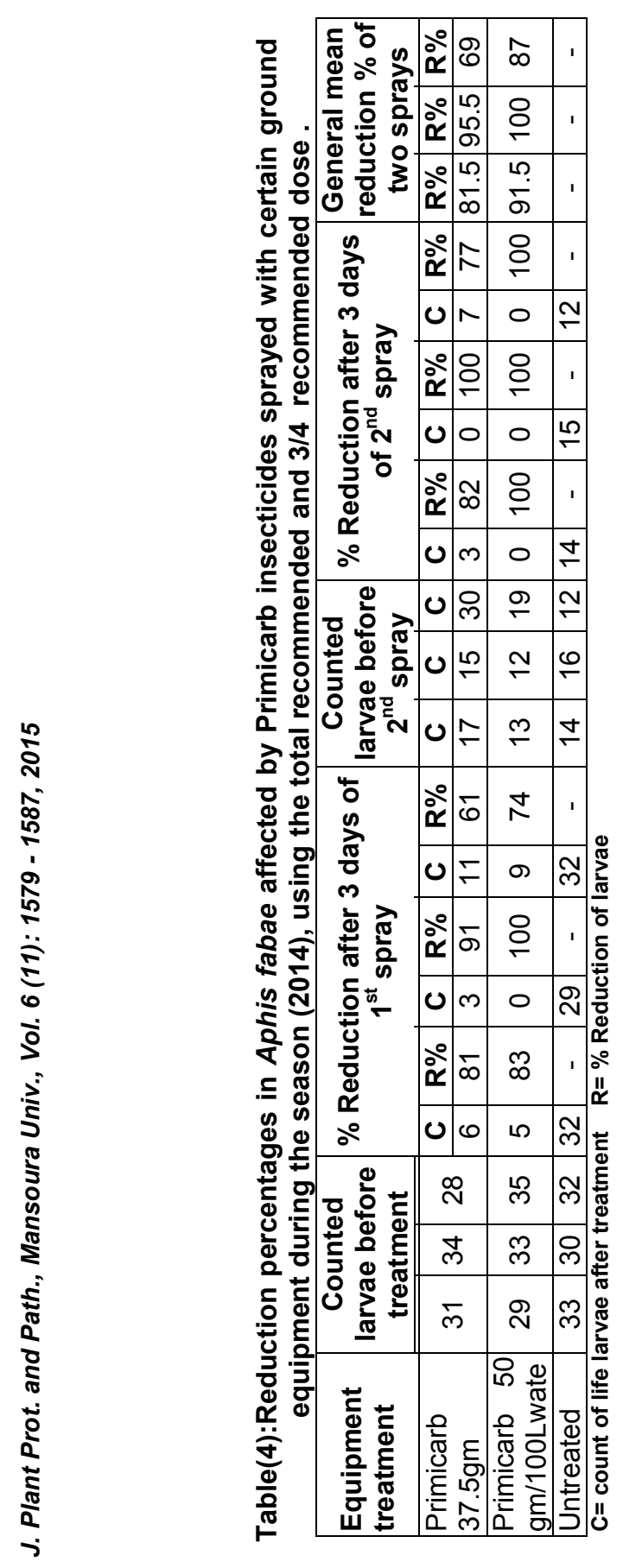

